openings for the able-bodied unemployed, particularly young men.

The Commissioner for the Special Areas in Scotland* also insists on the necessity for a long view. A boom in the heavy industries is little more than a temporary relief, and the object should be to change the unstable industrial equilibrium by introducing as many secondary industries as possible. $\mathrm{He}$ concludes that no solution which aims at getting the older men back into ordinary wage-earning employment can wholly succeed. Despite its inherent difficulty,

* Report of the Commissioner for the Special Areas in Scotland for the period 1st September 1937 to 30th September 1938. (Cmd 5905.) Pp. viii +88 . (London: H.M. Stationery Office, 1938.) 18. $6 d$. net. some form of sub-economic development must be provided. The absence of any serious attempt to co-ordinate the activities of the various social service organizations in Scotland is criticized, and the Com. missioner considers that further expenditure from the Special Areas Fund would be fully justified if it welded into a strong national body the various organizations at present doing fine work in most difficult circumstances. In regard to industrial development, the Commissioner suggests that more might be done to help new and experimental processes, and that a scheme designed to foster new enterprise in the area should include encouragement of such processes, even if in the nature of things their ultimate success was bound to be problematical.

\title{
International Congress of Tropical and Sub-Tropical Agriculture
}

$\mathrm{T}$ HE eighth International Congress of Tropical and Sub-Tropical Agricul ture was held at Tripoli during March 13-17, under the presidency of Prof. Le Plae, honorary general director of agriculture to the Colonies' Ministry, Belgium, in the unavoidable absence of Prof. Franco Angelini, secretary-general of the International Federation of Technical Agriculturists (F.I.T.A.). Delegates from Italy, France, Belgium, Holland, Poland, Germany, Bulgaria and other countries attended the Congress, and Great Britain was represented by Sir John Russell, as chief Government delegate, and by Sir Arthur Hill.

The Congress was opened by H.E. Marshal Balbo, Governor-General of Libya, who also presided at the concluding meeting. At the opening meeting, papers were presented by Prof. Armando Maugini on "European Colonization and Native Agriculture in Tropical and Sub-Tropical Countries", by Count Edmond de Warren on "Agricultural Production of the Warm Countries" and by Prof. Le Plae on the "Professional Preparation of Native Agriculturists through Compulsory Instruction". The Congress then broke up into five sections. The first dealt with the possibilities of agriculture in tropical and subtropical countries, Sir John Russell being one of the presidents of this section. In the second section papers were read on agricultural problems relating to ecology, meteorology, erosion, irrigation and dry culture; while the third section dealt with various economic problems such as credit, labour, co-operation and marketing.

The fourth section was in two parts, one devoted to vegetable products, of which Sir Arthur Hill was one of the presidents. Numerous papers dealing with cotton, sugar-cane, rubber, olives and vines in North Africa, citrus, etc., were presented, and also papers dealing with forestry. In the other subsection, papers relating to animal products were read.

The fifth section was devoted to insect and fungus pests of cultivated crops.

Visits were paid to the Agricultural and Zootechnical Experiment Station near Tripoli where fine new laboratories have just been completed; the grounds contain a very representative collection of citrus species and varieties, and of vines, almonds and other trees of economic value. The citrus, including grapefruit, were bearing large crops.
Of particular interest were the visits to the new villages of Crispi, Michele Bianchi and Oliveti, which have been recently built. Crispi, only some four months old, is situated in a seemingly desert plain and consists of some 333 farms with a civic centre where the church, town hall with cinema, hospital, school and co-operative store are arranged around a central square. The farms allotted to each colonist are 37-120 acres in extent according to the locality, part being irrigated for the growing of wheat, lucerne, cotton, etc., the rest being dry-farmed with olive and almond trees and vines.

Crispi with its new white houses in this sandy spot was not a prepossessing sight, but a visit to Bianchi and Oliveti, nearly three years old, was a revelation of the possibilities of irrigation and good cultivation, since at the start they were founded on sites as sandy and barren as Crispi.

At these two villages, the olive and almond trees were flourishing and beginning to bear, and the irrigated crops were in very good condition-a great tribute to the good work of the Italian colonists from the Venetian plain and to the foresight of the organizers of these remarkable developments. No doubt in Roman times much of this North African 'desert' country was fertile, else such magnificent cities as Leptis Magna and Sabratha would not have been founded.

The new colonist is provided with his house, sheds and farm on trust, together with the equipment and livestock. After a short time on a fixed salary, he is placed on a crop-sharing basis for about five years and in the sixth year he becomes full owner of the farm and assumes direct management. At the end of nine years, when he has paid one-third of his debt, the colonist becomes full owner of his farm. The whole debt is expected to be paid off before the end of the thirty-fifth year.

This eighth Congress was admirably organized by Dr. Gioacchino Dallari, colonial adviser of the Fascist Confederation of Land Workers, and his staff. The majority of delegates were conveyed from Genoa, Naples or Messina in the S.S. Roma, a fine cruiser of 30,000 tons which served as their headquarters during the Congress.

It was suggested that the Congress in 1941 might be held in England. 